we have never succeeded in cultivating the bacillus, which, if the bacillus lived as a saprophyte on decaying fish, would be a very simple matter. And there are, secondly, places where the inhabitants certainly and frequently employ decaying fish without the disease appearing. And thirdly, there are many places authoritatively indicated where leprosy is present, and where no fish is eaten." Very truly yours,

Albert S. Ashmead, M.D.

\section{Reply to Dr. Anders.}

Chicago, A pril 5, 1897.

To the Editor:-In reply to Dr. Anders' inquiry I can say that the First Methodist Episcopal Church of Waukegan, Ill., which has a membership of 300 , has used the individual communion cup for four years. It met with general approbation from the beginning, only two or three members refusing to participate. It is a complete success, as the details have been conveniently arranged.

Respectfully,

J. M. G. Carter, M.D.

\section{NEW INSTRUMENTS.}

\section{A MODIFICATION OF BOSWORTH'S NASAL AND AURAL SNARE. \\ BY I'. L. ANDLRSON, M.D. CHICAGO.}

Long experience with the various snares on the market has demonstrated that while they all have their individual points of excellence, no one snare combines all of the good qualities without some of the bad ones. The accompanying cuts show by comparison, the simplicity and advantages of the Bosworth snare as modified by the author.

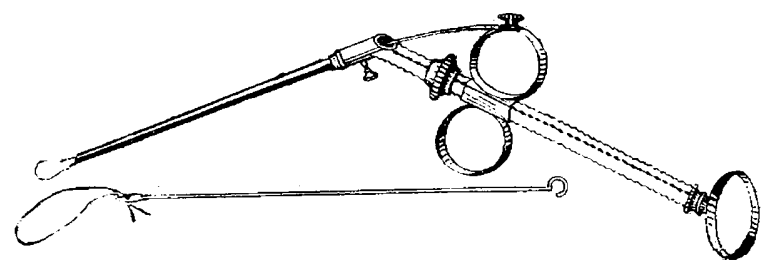

ANDERSON'S MODIFICATION OF BOWWORTH'S SNARE.

Instead of the long wire loop, there is substituted a flexible steel stilette, with one end flattened and having a round eye large enough to receive a double thread of No. 5 piano wire; the other end terminates in a circular hook, the central point of which is in line with the long axis of the stilette. The stilette is inserted into the canula of Bosworth's snare with the eye projecting just beyond the distal end, in position for

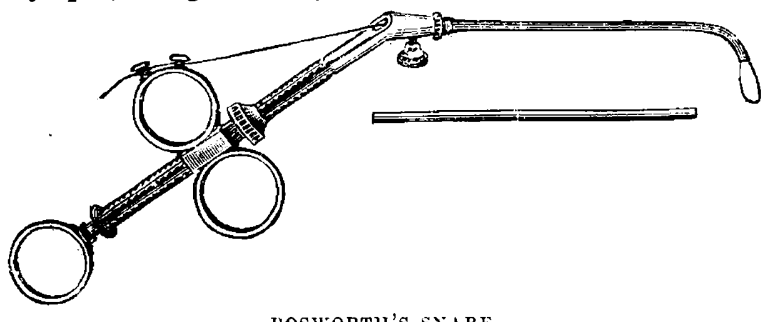

BOSWORTH'S SNARF.

threading with the short loop of wire. The other end is hooked around a screw-post set into the upper finger-ring of the sliding handle. This post is provided with a thumb-screw which securely holds in place the hook, allowing the stilette to slide either forward or backward. The advantages of this modification are:

1. The facility for threading the stilette with a short wire loop instead of using the long wire loop and having to pass it through the canula and fasten to the retention pin.

2. The wire loop may be bent to any curve and withdrawn into the canula so that but about one-half inch of the loop projects, thereby leaving it small and very convenient to introduce into the nose. After it is in the nose, the loop is easily projected farther by the sliding handle, and being of the flexible steel, assumes its original upward, bent position. This allows the operator to introduce the instrument, adjust the loop and complete the snaring by the use of one hand only, which gives the eye a complete view of the entire field of operation and leaves the other hand free to hold the speculum.

3. It is easily taken apart and cleansed after each operation, and is no more expensive than a Bosworth.

84 Dearborn Street.

\section{PUBLIC HEALTH.}

The Water Supply at Greater New York.-Among the liberal concessions to the public, may be noted the local Board of Health agitation regarding the water supply of the village of Flushing, Long Island. A communication to the State Board has been forwarded requesting the adoption of a resolution providing for the same protection as is already in effect in the Brooklyn water supply. It is to be hoped that the "Borough" of Brooklyn will balk the efforts of its contractors to become of themselves suddenly rich at the expense of the already overburthened tax-payers. Luxuries are very costly.

Contagion in Public Schools.-The New York Health Board staff of medical inspectors reported as the result of their first day's work: Number of boys examined 2,565, girls 1,690; cases of measles, 3 ; diphtheria, 14 ; scarlet fever, 1 ; mumps 3 ; eye diseases, 35 ; parasitic diseases of the head, 55 ; parasitic diseases of the body, 12 ; chickenpox, 8 ; cutaneous diseases, 8 . These cases were presented by the teachers of the primary departments as being the most under suspicion, the remainder and the higher grades to be examined are not expected to give near the number just reported. The Board, however, think the result justifies the importance of the system, inasmuch as very many parents studiously avoid calling in a physician at all, rating school advantages above every other consideration.

The Bacteriology of Rinderpest.-This epizoötic disease was recognized as early as 1715 ; it again made its appearance in 1745 , and in 1865 there was a tremendous outbreak, which led to the Royal Commission and the stamping out order of 1866 . Since that time only a small outbreak in 1872 has been recorded, and this was stamped out almost immediately. It is, however, stated to be epizoötic in Asiatic Russia, in Hindoostan, Persia, China, and even Ceylon, but on this point it is difficult to obtain very accurate information. From the very first the disease was stamped as contagious, and several attempts have been made to trace the fons et origo mali. Murchison maintained that the cattle plague resembled smallpox in all but the cutaneous eruption, but further acquaintance with the disease did not allow of the analogy being carried very far. The disease, however, runs the course of a specific infective fever, the incubation period is short, the symptoms are marked, and the pathological changes are definite.

The contagion was by Burdon Sanderson localized in the blood as well as in the discharges, and in his report to the commissioners appointed to inquire into the origin and nature of the cattle plague, he pointed out that the serum separated from the blood of an animal suffering from this disease contained the contagium which could be transmitted by experimental infection to other animals. Beale described cocci ; Sanderson and Smart of Edinburgh, saw them also, and in 1883 Semner brought up the subject again, and described streptococci as the cause of the disease. Whether these cocci are primary or secondary still remains to be seen and proved, but from the whole nature of the disease we should expect to find some "contagium vivum" as its primary cause-a contagium which is 